\title{
The digestion of perennial ryegrass (Lolium perenne cv. Melle) and white clover (Trifolium repens $\mathrm{cv}$. Blanca) by grazing cattle
}

\author{
By M. J. ULYATT*, D. J. THOMSON, D. E. BEEVER†, R. T. EVANS \\ AND M. J. HAINES \\ AFRC Institute for Grassland and Animal Production, Hurley Research Station, Hurley, \\ Maidenhead, Berks. SL6 5LR
}

(Received 19 September 1986 - Accepted 19 February 1988)

1. Pure swards of perennial ryegrass (Lolium perenne $\mathrm{cv}$. Melle) as a primary growth (May), trimmed primary growth (early June) and regrowth (late June), and white clover (Trifolium repens cv. Blanca) as a mature primary growth (July) and vegetative regrowth (August), were grazed by twelve Friesian steers (mean body-weights throughout experiment $152-231 \mathrm{~kg}$ ) at daily allocation rates of forage which provided dry matter (DM) intakes ranging from 28 to $36 \mathrm{~g} / \mathrm{kg}$ body-weight).

2. Total nitrogen contents of the three ryegrasses declined with season $(37-20 \mathrm{~g} / \mathrm{kg} \mathrm{DM})$, but in vitro organic matter (OM) digestibilities were relatively constant $(0.760 .79)$. The clovers had higher $\mathrm{N}$ (average $36.6 \mathrm{~g} / \mathrm{kg} \mathrm{DM})$ and lower fibre and water-soluble carbohydrate contents than the grasses, and in vitro OM digestibilities of 0.70 and 0.76 respectively.

3. Duodenal digesta samples were obtained, using a portable sampling apparatus from the animals grazing the pasture, and estimates of the flow of nutrients into the small intestine were derived using two indigestible markers which were continuously infused into the rumen using a portable infusion apparatus. Forage intakes were calculated from estimates of faecal output of indigestible OM and the predicted in vivo OM digestibilities of the forages consumed. Coefficients of variation for OM flow to the small intestine and OM intake were 11.8 and $10.9 \%$ respectively.

4. The apparent digestion of $O M$ in the rumen ranged from 722 to $741 \mathrm{~g} / \mathrm{kg}$ digestible $O M$ intake and from 681 to $711 \mathrm{~g} / \mathrm{kg}$ digestible $O M$ intake for the grass and clover diets respectively. Substantial losses of ingested $\mathrm{N}$ before the small intestine were measured on all diets except the regrowth ryegrass. Losses were $0 \cdot 30$ and $0.40 \mathrm{~g} / \mathrm{g} \mathrm{N}$ intake on the primary growth ryegrass and the regrowth clover respectively; $\mathrm{N}$ contents were 37 and $39 \mathrm{~g} / \mathrm{kg} \mathrm{DM}$ respectively.

5. Comparison of the values obtained at pasture with that obtained when similar diets were offered to housed cattle (Beever et al. 1985) indicated that combined relations relating duodenal OM and non-ammonia-N (NAN) flows to $\mathrm{OM}$ and $\mathrm{N}$ intakes respectively could be established for each diet. For two diets (primary-growth grass and regrowth clover) the relations were curvilinear; for the remaining diets, the derived relations were linear.

6. The effects of forage species, stage of maturity and variations in the stem : leaf ratio in the grasses, on nutrient supply in grazing animals are discussed, and a combined relation for all grazed and harvested forages examined in this and in a previous study reported by Beever $e t$ al. (1985) is established. The relation $Y=1 \cdot 430-0 \cdot 0169 X$ ( $r 0.72$, residual SD $0 \cdot 140$ ), where $Y$ is NAN flow $/ \mathrm{N}$ intake $(\mathrm{g} / \mathrm{g})$ and $X$ is $\mathrm{N}$ content in the crop $(\mathrm{g} / \mathrm{kg} \mathrm{OM})$, indicates that net losses of $\mathrm{N}$ across the rumen will occur on diets which contain more than $25.5 \mathrm{~g} \mathrm{~N} / \mathrm{kg} \mathrm{OM}$.

7. Possible limitations in the techniques available to measure nutrient digestion and supply in grazing ruminants are discussed.

In recent years, considerable advances have been made in the nutrition of ruminant livestock, aided by the development and use of techniques to partition digestion within the alimentary tract between fermentative (reticulo-rumen) and endogenous enzymic (intestines) modes. This research has led to changes in our concepts of nutrient digestion and supply in ruminants, especially with respect to protein (e.g. Agricultural Research Council, 1980).

This work has, however, concentrated on conserved forages and diets containing a high proportion of concentrates. Published work with fresh forage has been restricted to a limited number of experiments mainly conducted with housed animals (Beever et al. 1974,

\footnotetext{
* Present address: DSIR, Biotechnology Division, Palmerston North, New Zealand.

$\dagger$ For reprints.
} 
1976, 1978; MacRae \& Ulyatt, 1974; Ulyatt \& MacRae, 1974; Ulyatt \& Egan, 1979; Verite et al. 1984). Due to technical difficulties there have been few attempts to examine nutrient digestion and supply in ruminants grazing fresh forages (Corbett et al. 1976; Cruikshank et al. 1985; Beever et al. 1986 b). However, workers in Australia and the UK have developed portable infusion pumps (Corbett et al. 1976; Evans et al. 1981 b) and duodenal sampling apparatus (Evans et al. $1981 \mathrm{~b}$ ) suitable for the measurement of nutrient flow into the small intestine of either sheep or cattle at pasture. The results presented in the present paper are from an experiment using such approaches with grazing cattle, the objective being to quantify the effects of forage species (grass $v$. white clover) and the ratio leaf:stem of grasses of similar digestibilities on nutrient digestion and supply. The diets used in the present study were similar to those described by Beever et al. (1985) which were harvested daily and offered to cattle indoors. In the present paper the findings on nutrient supply obtained from both studies are compared, and the suitability of using values obtained with a cut forage to evaluate grazed forage is examined.

\section{EXPERIMENTAL}

\section{Forages}

A description of the two pasture species i.e. perennial ryegrass (Lolium perenne cv. Melle) and white clover (Trifolium repens cv. Blanca) and the pre-experimental and experimental management of the two swards has been given by Beever et al. (1985).

Briefly, the two forages were offered to growing cattle in the following sequence comprising five experimental periods: 1 (2 to 23 May 1979) primary-growth ryegrass (R1); 2 (24 May to 13 June 1979) trimmed primary-growth ryegrass (R2); 3 (14 June to 4 July 1979) regrowth ryegrass (R3); 4 (5 July to 1 August 1979$)$ mature white clover (W1); 5 (2 to 30 August 1979) regrowth white clover (W2). Fertilizer management of both swards, establishment of grazing plots, and the stages of growth of the forages and post-grazing management were as indicated by Beever et al. (1985).

\section{Animals and their management}

Twelve castrated Friesian calves, aged 3-4 months and weighing $130 \mathrm{~kg}$ (average) were prepared with a PVC rumen cannula (i.d. $13 \mathrm{~mm}$ ) and a PVC ' $T$ '-piece duodenal cannula (i.d. $20 \mathrm{~mm}$ ) anterior to the bile duct. In addition two animals aged 12 months and weighing on average $330 \mathrm{~kg}$, which had been previously prepared with similar rumen and duodenal cannulas, were maintained with the experimental group in order to assess whether indigestible markers infused into the twelve experimental animals were ingested to any appreciable extent as a result of faecal contamination of the pasture.

During the experiment, the calves were allowed to graze continuously apart from two occasions each day (approximately $45 \mathrm{~min}$ each) at 08.30 and 16.00 hours, when they were taken to an adjacent shed for removal of collected digesta samples (as appropriate), checking and adjustment of harnesses and infusion and sampling equipment, and general animal maintenance including recording of body-weight. In addition, during periods 4 and 5 when white clover was being examined, all animals were dosed orally at these times with $5 \mathrm{ml}$ Poloxalene (Smith, Kline \& French; Welwyn, Herts; $980 \mathrm{ml} / \mathrm{l}$ ) to prevent legume bloat. Animals had free access to fresh water at all times and mineral blocks were provided, except for the last 2 weeks of each experimental period when measurements of feed intake and duodenal flow were made. All animals were weighed weekly.

\section{Pasture management and feed allocation}

The objective was to provide sufficient forage daily to allow a dry matter (DM) intake within the range $18-26 \mathrm{~g} / \mathrm{kg}$ body-weight, which coincided with the feeding levels adopted 
by Beever et al. (1985) in the concurrent indoor experiment. This was estimated from Baker (1978) to require a daily allowance of standing crop of $56 \mathrm{~g} \mathrm{DM} / \mathrm{kg}$ body-weight, with measurements of standing crop being made by cutting quadrats of the crop to ground level.

Two systems of pasture allocation were used during the experiment. In period 1 (R1), each plot was internally divided by electric fences into three subplots each approximately $12 \mathrm{~m}$ wide, and each subplot was grazed in turn. The amount of DM on offer was estimated from six quadrats (each $0.24 \mathrm{~m}^{2}$ ) cut to ground level each morning from the new day's allocation, and DM content was estimated using a modified microwave oven. The length of subplot required to provide $56 \mathrm{~g} \mathrm{DM} / \mathrm{kg}$ body-weight was then calculated and this was divided into two equal portions by an electric fence, to provide morning and afternoon feed allocations. This system of feed allocation resulted in a high stocking density and considerable wastage of pasture occurred through trampling. For periods 2 and 3 , this procedure was changed by increasing the width of the plot to $24 \mathrm{~m}$ and forage allocation was based on DM yields determined over the $3 \mathrm{~d}$ before each measurement period. When the required length of plot had been determined, this was not varied for the duration of the measurement period; furthermore, the calves were allowed free access to the allocation of each previous day as a rest area to encourage loafing-lying off the experimental feed. This alternative management was found to reduce trampling of the offered forage, and resulted in a more satisfactory utilization of the forage.

Similar systems of pasture management were used for periods 4 and 5 (W1 and W2 respectively) but the width of each plot was increased to $30 \mathrm{~m}$.

\section{Sampling methods}

Forages. Samples were taken according to the procedures described previously, and used to determine DM yields of the offered crops by drying in a forced-draught oven for $24 \mathrm{~h}$ at $103^{\circ}$. Forage residues were taken after grazing each day during each digesta collection period between 08.30 and 10.00 hours by means of six quadrats cut to ground level, and samples of the resulting forage were dried for $24 \mathrm{~h}$ at $103^{\circ}$.

Samples representative of the consumed forage were obtained from the pasture offered in the morning and afternoon, before grazing, by hand cutting at the residual grazing height observed on the paddock from the previous day. These samples were immediately frozen and subsequently bulked over each collection period on an equal DM basis.

Duodenal digesta. The twelve calves were divided into two equal groups (A and B) and collections of digesta from each group were staggered by approximately $4 \mathrm{~d}$, similar to the procedures adopted by Beever et al. (1985) to maximize use of a limited number of automatic duodenal samplers. Infusions of markers into the reticulo-rumen (CrEDTA and ruthenium phenanthroline $(\mathrm{Ru})$ (Faichney, 1975)) were commenced $13 \mathrm{~d}$ (group A) and $8 \mathrm{~d}$ (group B) before the end of each experimental period using the portable pumps described by Evans et al $(1981 a)$ with dose rates as described by Beever et al. (1985); i.e. $120 \mathrm{mg} \mathrm{Cr}$ and $12 \mathrm{mg} \mathrm{Ru} / \mathrm{kg}$ expected DM intake. After $5 \mathrm{~d}$ of continuous marker infusions, two $24 \mathrm{~h}$ continuous collections of duodenal digesta were undertaken using the apparatus described by Evans et al $(1981 \mathrm{~b})$. Collected samples of digesta were removed from each animal at $16.00,21.00$ and finally 09.00 hours on each day, subsequently bulked for each $24 \mathrm{~h}$ and processed for analysis according to the procedures adopted by Beever et al. (1985), by preparation of the appropriate whole and centrifuged digesta samples.

In addition, when the duodenal samples were removed from the experimental animals, spot samples of duodenal digesta were obtained from the two non-experimental steers. These samples were freeze-dried directly, without processing, to provide samples of whole digesta only.

Faeces. During the last $3 \mathrm{~d}$ of each infusion period, faecal material was obtained from all 
calves by grab sampling at approximately 09.00 and 16.00 hours. Each sample was oven dried $\left(24 \mathrm{~h}\right.$ at $\left.103^{\circ}\right)$ and daily bulk samples for each animal were prepared on an equal DM basis.

\section{Sample analysis}

Before chemical analysis, all samples of feed, duodenal digesta and faeces were freeze-dried, then ground to pass through a $1 \mathrm{~mm}$ sieve. Samples of duodenal digesta and faeces for $\mathrm{Ru}$ analysis ( $3 \mathrm{~g}$ ) were subsequently ball milled and finally pelleted (Evans et al. 1977).

Analysis of samples, as required, for organic matter (OM), gross energy, nitrogen, ammonia, cellulose, water-soluble carbohydrate, neutral-detergent fibre and in vitro $\mathrm{OM}$ digestibility were as described by Beever et al. (1985).

\section{Calculation of results}

The flows of digesta, and its constituents, into the small intestine of the calves were calculated according to the procedures proposed by Faichney (1975), and mean $24 \mathrm{~h}$ flows for each animal were obtained. Duodenal digesta samples obtained from the two nonexperimental animals throughout the whole season contained no significant concentrations of $\mathrm{Ru}$ and $\mathrm{Cr}$ and, consequently, background corrections to the samples obtained from the experimental animals were not necessary. Estimates of faecal OM output were derived from faecal $\mathrm{Ru}$ content (expressed on an $\mathrm{OM}$ basis) and daily $\mathrm{Ru}$ dose rate, and these were used to calculate OM intake (OMI) according to the equation:

$$
\mathrm{OMI}=\frac{\text { faecal OM output }}{1-D}
$$

where $D$ is the estimated in vivo OM digestibility, calculated from:

$$
D=1.04 X+0.00246(r 0.871 ; n 45),
$$

where $X$ is the measured in vitro OM digestibility ( $\mathrm{g} / \mathrm{kg}$ total $\mathrm{OM}$ ) of the samples taken to represent consumed forage. Eqn (2) was derived from in vitro and in vivo OM digestibility values obtained in the indoor feeding experiment reported by Beever et al. (1985) for diets corresponding to those used in the present study.

Owing to the nature of the experiments, the dietary treatments were totally confounded with time, such that the amounts of forage consumed increased as the season advanced in response to the increased live weight of the animals. The results are presented both in terms of total quantities of nutrients flowing through the alimentary tract and in relation to live weight as these were found, from the statistical analysis, to be the most appropriate ways of illustrating the experimental values. Alternative ways of expressing the values (e.g. in relation to metabolic body size, live weight $t^{0.75}$ ) were examined but dismissed on the basis that they did not result in any change in the conclusions which could be drawn from the study. To permit further examination of the experimental values by the reader, if deemed appropriate, the mean body-weights of the animals for each period-diet are presented.

\section{Statistical analysis}

Treatment means were compared in a split-plot analysis of variance after tests (Bartlett, 1937) showed that variances and correlations could be treated as equal over five growth periods. There were no main-plot treatments giving thirty-six subplot error df due to eight missing values (one in period 2 (R2), two in period 4 (W1) and five in period 5 (W2)). Further comparisons were made using regression analysis of nutrient flow on nutrient intake. 
Table 1. The botanical and chemical composition $(\mathrm{g} / \mathrm{kg}$ dry matter (DM) unless stated) of the three perennial ryegrass (Lolium perenne $c v$. Melle; $R$ ) and two white clover (Trifolium repens $c v$. Blanca; $W$ ) diets offered to calves

\begin{tabular}{|c|c|c|c|c|c|}
\hline & \multicolumn{3}{|c|}{ Perennial ryegrass } & \multicolumn{2}{|c|}{ White clover } \\
\hline & $\mathbf{R} 1$ & R2 & R3 & W1 & W2 \\
\hline \multicolumn{6}{|l|}{ Botanical composition } \\
\hline Leaf* & 924 & 730 & 702 & 658 & 887 \\
\hline Stem & 64 & 213 & 270 & - & - \\
\hline Dead & 2 & 0 & 23 & 13 & 25 \\
\hline Flower head & - & - & - & 327 & 85 \\
\hline Purity & 990 & 943 & 995 & 998 & 997 \\
\hline \multicolumn{6}{|l|}{ Chemical composition } \\
\hline Organic matter & 908 & 912 & 913 & 922 & 902 \\
\hline Water-soluble carbohydrate & 128 & 132 & 187 & 93 & 103 \\
\hline Cellulose & 214 & 244 & 206 & 232 & 201 \\
\hline Neutral detergent fibre & 396 & 447 & 405 & 316 & 241 \\
\hline Nitrogen & $37 \cdot 1$ & $31 \cdot 4$ & $20 \cdot 2$ & $34 \cdot 6$ & $38 \cdot 6$ \\
\hline Gross energy (MJ/kg DM) & $19 \cdot 4$ & 18.9 & $18 \cdot 1$ & $19 \cdot 3$ & $18 \cdot 8$ \\
\hline $\begin{array}{l}\text { In vitro organic matter } \\
\text { digestibility }\end{array}$ & 786 & 764 & 787 & 695 & 756 \\
\hline
\end{tabular}

* Includes petiole for clover.

\section{RESULTS}

Composition of crops offered

The botanical composition of the five pasture diets as offered is given in Table 1. Species purity of all swards was high ( $>943 \mathrm{~g} / \mathrm{kg} \mathrm{DM}$ ), but there were marked differences between the grasses in leaf:stem ratios (14.4, 3.4 and 2.6 for $\mathrm{R} 1, \mathrm{R} 2$ and $\mathrm{R} 3$ respectively). The primary-growth clover (W1) had a higher proportion of flower head to leaf than the regrowth clover (W2).

There were differences in chemical composition between the ryegrass diets. $R 2$ contained more cellulose and neutral-detergent fibre but had less N than R1. R3 had a much lower content of $\mathrm{N}$ than either R1 or R2, but similar cellulose and neutral-detergent fibre contents to $\mathrm{R} 1$ and a higher water-soluble carbohydrate content that the other grasses. The in vitro OM digestibility for $\mathrm{R} 2$ was marginally lower than that for $\mathrm{R} 1$ and $\mathrm{R} 3$. Cellulose and neutral-detergent fibre contents were higher on W1 than W2, and both clovers had high $N$ contents but water-soluble carbohydrate contents were lower than those for the grasses. In vitro OM digestibility of the primary-growth clover was lower than the regrowth clover and the three grass diets.

\section{Nutrient intake, digestion and supply}

As indicated earlier, some problems were encountered within the experiment with respect to pasture growth and allocations. Consequently, the estimated mean DM intakes (i.e. R1 32, R2 28, R3 28, W1 29, and W2 $34 \mathrm{~g} / \mathrm{kg}$ live weight) were all higher than the mean intakes achieved with the housed cattle (Beever et al. 1985).

In Table 2 , the mean quantities of $O M$ and $N$ consumed, $O M$ and non-ammonia- $N$ (NAN) entering the small intestine, and rumen losses of apparently digestible $\mathrm{OM}(\mathrm{g} / \mathrm{kg}$ digestible OMI (DOMI)) and ingested N(g/d) are given. Mean OMI for the five diets ranged from 4.37 to $7.17 \mathrm{~kg} / \mathrm{d}$, and duodenal OM flows (from 1.72 to $3.04 \mathrm{~kg} / \mathrm{d}$ ) reflected these differences, but the values for the clover diets were significantly higher $(\boldsymbol{P}<0.01)$ than 
Table 2. Mean quantities of organic matter $(\mathrm{kg} / \mathrm{d})$ and nitrogen $(\mathrm{g} / \mathrm{d})$ consumed, flowing into the small intestine (as non-ammonia- $N ; N A N$ ) and present in the faeces (organic matter only) for three perennial ryegrass (Lolium perenne $c v$. Melle; $R$ ) and two white clover (Trifolium repens $c v$. Blanca; W) swards offered to grazing cattle

(Values for the extent of rumen digestion of digestible organic matter and total N, and NAN flow/unit $\mathrm{N}$ intake are also given)

\begin{tabular}{|c|c|c|c|c|c|c|}
\hline & \multicolumn{3}{|c|}{ Perennial ryegrass } & \multicolumn{2}{|c|}{ White clover } & \multirow[b]{2}{*}{ SEM } \\
\hline & Rl & R2 & $\mathbf{R} 3$ & W1 & W2 & \\
\hline Mean body-wt of animals $(\mathrm{kg})$ & $152 \cdot 4$ & $171 \cdot 2$ & $189 \cdot 1$ & $208 \cdot 2$ & $231 \cdot 0$ & $2 \cdot 01$ \\
\hline \multicolumn{7}{|l|}{ Organic matter } \\
\hline Consumed $(\mathrm{kg} / \mathrm{d})$ & 5.02 & $4 \cdot 37$ & $4 \cdot 82$ & 5.53 & $7 \cdot 17$ & 0.152 \\
\hline Entering small intestine $(\mathrm{kg} / \mathrm{d})$ & 1.97 & $1 \cdot 72$ & 1.85 & $2 \cdot 70$ & 3.04 & 0.078 \\
\hline In faeces $(\mathrm{kg} / \mathrm{d})$ & 0.83 & 0.82 & 0.79 & 1.39 & 1.36 & 0.034 \\
\hline Apparent digestibility ( $\mathrm{g} / \mathrm{kg}$ intake) & 835 & 815 & 836 & 752 & 808 & \\
\hline $\begin{array}{l}\text { Extent of rumen digestion of } \\
\text { digestible organic matter }(\mathrm{g} / \mathrm{kg} \\
\text { apparently digested) }\end{array}$ & 722 & 741 & 738 & 681 & 711 & $19 \cdot 49$ \\
\hline \multicolumn{7}{|l|}{$\mathrm{N}$} \\
\hline Consumed $(\mathrm{g} / \mathrm{d})$ & $205 \cdot 0$ & $151 \cdot 3$ & $106 \cdot 5$ & $208 \cdot 5$ & $306 \cdot 7$ & 5.64 \\
\hline $\begin{array}{l}\text { Entering small intestine (as NAN) } \\
(\mathrm{g} / \mathrm{d})\end{array}$ & $140 \cdot 7$ & $115 \cdot 6$ & $122 \cdot 0$ & $151 \cdot 3$ & $184 \cdot 1$ & $5 \cdot 24$ \\
\hline Rumen loss of $\mathrm{N}^{*}(\mathrm{~g} / \mathrm{d})$ & $64 \cdot 3$ & $35 \cdot 7$ & $15 \cdot 5$ & $57 \cdot 2$ & $122 \cdot 6$ & 6.54 \\
\hline NAN flow (g/kg N intake) & 0.70 & 0.77 & $1 \cdot 14$ & 0.72 & 0.60 & 0.035 \\
\hline
\end{tabular}

those recorded for the grass diets. Coefficients of variation for OM flow to the small intestine averaged $11.8 \%$ on all diets, compared with $10.9 \%$ for estimates of OM intake. On the grass diets, OM digestion in the rumen in relation to DOMI showed little variation from the mean value of $734 \mathrm{~g} / \mathrm{kg}$ DOMI whilst the value observed on W2 $(711 \mathrm{~g} / \mathrm{kg})$ was marginally but not significantly $(P>0.05)$ lower. In contrast, the value for W1 $(618 \mathrm{~g} / \mathrm{kg})$ was significantly $(P<0 \cdot 05)$ lower than the values for the three grasses but not significantly $(P>0.05)$ different from the value obtained on $\mathrm{W} 2$. There was a threefold range in daily $\mathrm{N}$ intakes for the five diets, but duodenal NAN flows showed a narrower range due in part to large losses of $\mathrm{N}$ across the reticulo-rumen, especially on diets R1, W1 and W2, which all had high dietary $\mathrm{N}$ contents. On diet $\mathrm{R} 3$, which had the lowest dietary $\mathrm{N}$ content, there was an increase in NAN flow into the small intestine relative to the amount consumed. NAN flow per unit $\mathrm{N}$ intake ranged across the diets from 0.60 (W2) to $1 \cdot 14$ (R3).

\section{DISCUSSION}

The main objectives of the present experiment were to evaluate the portable infusion and duodenal sampling apparatus as described by Evans et al. $(1981 a, b)$ to estimate nutrient flow in grazing animals and to compare the results obtained with those derived from similar cattle fed indoors on known amounts of the same forages harvested daily by cutting. Additionally, the use of contrasting forage species, and the deliberate establishment of different leaf:stem values within the three ryegrasses provided the opportunity to examine further the effects of forage composition (both chemical and physical) on nutrient supply. 


\section{Techniques and methodology in measuring nutrient flow}

The apparatus described by Evans et al. $(1981 a, b)$ was used for the first time under rigorous field conditions, and, from an intended total of 572 animal days of infusion of markers into the rumen with the peristaltic pumps, only $23 \mathrm{~d}(4 \%)$ were unsatisfactory, due in part to battery failure, split infusion tubes and occasional misplacement of the harnesses which secured the pumps. Equally, $92 \%(n 110)$ of the planned duodenal collections $(n 120)$ were successfully completed, and reasons why ten duodenal collections had to be discarded were related to digesta blockages, tubing disconnected from the duodenal cannulas or occasional sampler malfunction (e.g. valve remaining open). All such faults were rapidly corrected and overall success rate was good. The health of the animals and the levels of feed consumption were satisfactory at all times; during the experiment the calves gained an average of $80 \mathrm{~kg}$ body-weight, equivalent to a daily gain of $0.73 \mathrm{~kg}$.

\section{Limitations on nutrient-supply values derived from grazing animals}

Estimation of nutrient flow to the small intestine of grazing animals will be affected by the accuracy of the marker techniques adopted and adequacy of the sampling procedures used, in a similar manner to the estimation of nutrient flow in stall-fed animals. Additionally, performance and reliability of the automatic infusion and sampling apparatus may place another constraint on the determination of such values, as discussed previously. The usefulness of such values in the nutritional evaluation of grazed forage, however, is greatly enhanced if measurements of feed intake and faecal output can be obtained in parallel with estimates of nutrient flow. To obtain such values, a variety of techniques has been proposed (Langlands, 1975). One essential prerequisite is an estimation of the composition of the consumed forage. In this regard, animals with oesophageal fistulas would have been appropriate in the present study, but bearing in mind the degree of surgical modification required to estimate nutrient flow, the establishment of a further fistula was considered inappropriate. Thus in the present study hand-plucked samples of the offered forage were taken as representative of the consumed forage. Clearly this could constitute a major limitation on the interpretation of the values obtained in the present study.

From estimates of in vitro digestibility of the forage samples considered to be representative of the consumed forages, in vivo values of digestibility were calculated using the relation obtained from a concurrent indoor-feeding experiment (Beever et al. 1985). It is difficult to comment on the suitability of this approach, but it is possible that the estimates may have been subject to bias as the cattle grazing the forages had considerable opportunity to exert selective preferences within the sward, and during periods $2-5$ to graze from the allocation of the previous day. In the concurrent indoor-feeding experiment (Beever et al. 1985), grab samples of faeces were obtained using the same infusion and sampling protocol adopted in the present experiment. Estimates of DM intake were calculated using the feed: faeces ratio method (Langlands, 1975) with measurements of in vitro $O M$ digestibility being used to predict in vivo OM digestibility. These predicted OMI $(Y, \mathrm{~g} \mathrm{OM} / \mathrm{d})$ were subsequently related to measured OMI $(X, \mathrm{~g} \mathrm{OM} / \mathrm{d})$ obtained in the indoor experiment, and the following regression equation was derived:

$$
Y=0.98 \text { (SE 0.08) } X+274 \text { (SE 322) } \quad r 0.87 \text {. }
$$

From this it may be calculated that for a predicted intake $(Y)$ of $5000 \mathrm{~g} \mathrm{OM} / \mathrm{d}$, based on the feed: faeces ratio method, the true OMI $(X)$ would be $4822 \mathrm{~g} / \mathrm{d}$, indicating an overprediction of intake equivalent to $3.7 \%$ of the true value.

In the present study, faecal OM output was calculated from faecal dilution of an indigestible marker $(\mathrm{Ru})$ which was infused continuously into the rumen, and estimated 
forage in vivo digestibility calculated as described previously. There are several potential sources of error in these procedures. Whilst the marker used was considered acceptable as judged by the criteria given by Kotb \& Luckey (1972), the timing of the faecal samples could lead to errors in the estimation of faecal output. In the present study only two sampling times ( 09.00 and 16.00 hours each day) were used, as these times have been shown to give representative faecal samples with respect to marker concentrations when chromic oxide administered twice daily is used (Langlands, 1975). However, the pattern of marker concentration in faeces when the marker is administered continuously has not been established, and it was not possible in the present study to identify the most appropriate times for faecal sampling, within each day. More frequent faecal sampling, and increasing the number of successive days of sampling, may have improved the estimation of faecal output, and hence intake, but at the same time could have seriously disturbed the grazing pattern of the animals.

Despite the limitations in the approaches adopted, the coefficients of variation in estimates of OM flow to the small intestine, and OMI, appeared to be satisfactory. In relation to the live weights of the animals, the estimated DM intakes were satisfactory (range 28-34 g/ $\mathrm{kg}$ live weight), and exceeded the highest plane of restricted feeding used by Beever et al. (1985), possibly reflecting the high forage allowances given in the present experiment. Furthermore, the findings relating to the digestion of OM (Table 2), indicating that between 681 and $741 \mathrm{~g} / \mathrm{kg}$ DOMI were apparently digested in the rumen on all diets, are consistent with values previously reported for such diets (Beever et al. 1986a). On this basis, the values presented in Table 2 appeared to be acceptable and suitable for further examination in relation to the objectives of the study as stated earlier.

\section{Comparison of cut and grazed forage}

Whilst the intention of the present experiment was to promote similar forage DM intakes to those achieved in the indoor study (Beever et al. 1985), problems were encountered with the allocation of the pasture and the estimated intakes were higher than those recorded for the stall-held cattle. Some indication of this effect is seen in Fig. 1 where values relating NAN flow to OMI for both the indoor and outdoor studies are presented. Furthermore, some differences in chemical composition between the mechanically harvested and grazed forages were observed. The grasses given indoors had a higher proportion of stem with slightly higher contents of carbohydrate constituents and lower $\mathrm{N}$ contents, whilst the harvested clovers had higher $\mathrm{N}$ and lower water-soluble carbohydrate contents than the corresponding grazed forages. However, all these differences were small, and whilst it may be inappropriate to ignore them, they were not considered at this stage to be of great nutritional significance.

Higher intakes in the grazing trial provided an extended range for the response variables and overall regression analysis was used to test whether curvilinearity was significant. In order to decide whether weighted overall analysis was required, separate regression equations (on a body-weight basis) describing the amounts of OM and NAN entering the small intestine $(Y)$ in relation to OMI and total $\mathrm{N}$ intake $(X)$ respectively were calculated for the corresponding forages offered indoors or grazed in situ (i.e. for each individual diet-period), and Bartlett's (1937) test of homogeneity of variances was applied to test the error variances obtained for each forage given indoors or grazed.

With the values available from the present study, the choice of components to include in the regression equations in order to test the values for homogeneity was limited. Previous studies have reported similar relations (Hogan \& Weston, 1970) and research has shown that the flows of OM and NAN into the small intestine are important nutritional indices in relation to the extent of rumen digestion and nutrient supply respectively. Furthermore, 

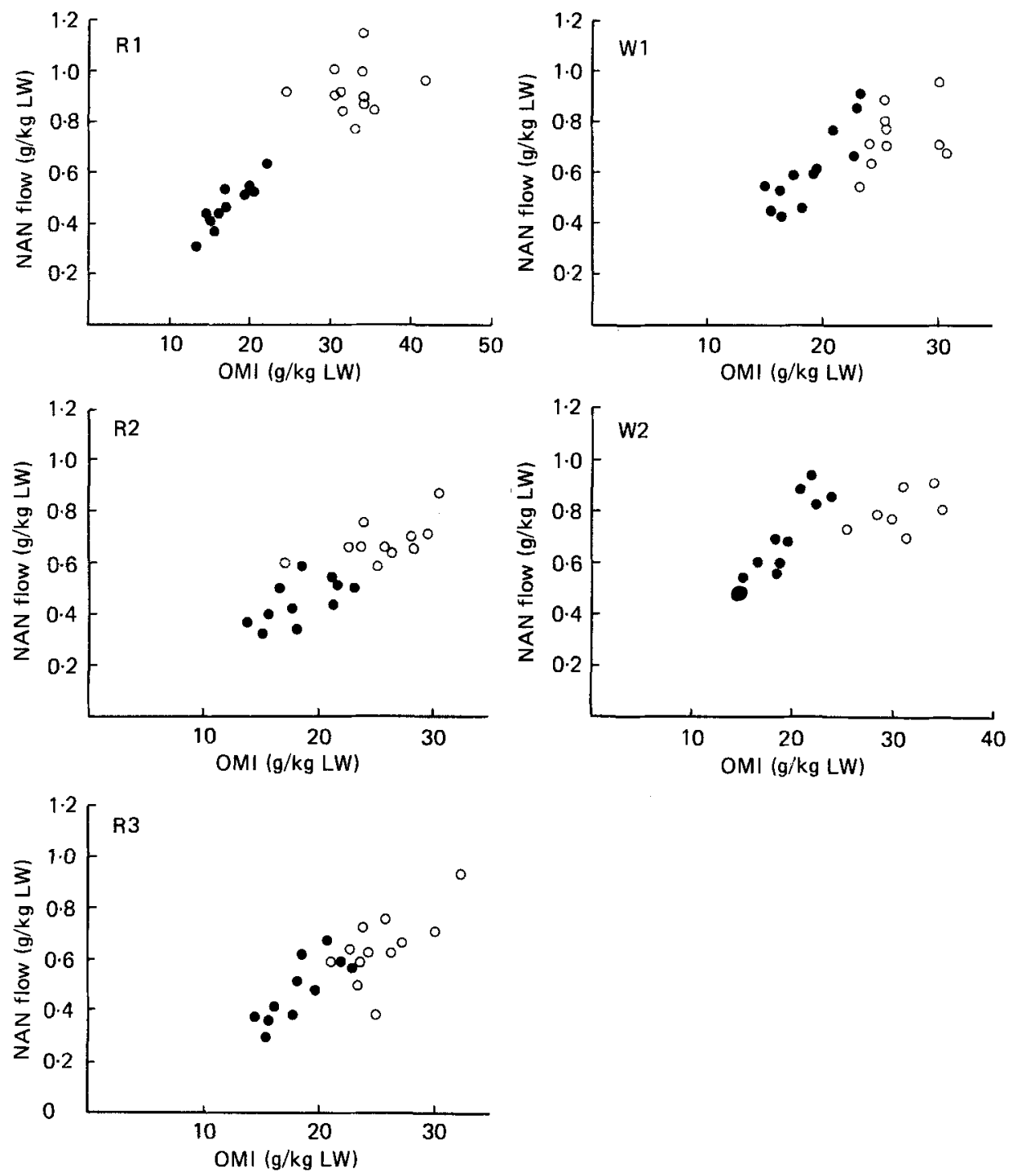

Fig. 1. Individual observations relating non-ammonia-nitrogen (NAN) flow to the small intestine to organic matter intake (OMI) for cattle grazing (O) or fed on harvested (O) perennial ryegrass (Lolium perenne cv. Melle; R1, R2 and R3) and white clover (Trifolium repens cv. Blanca; W1, W2) forages. LW, live weight.

OMI was used in preference to DM intake to avoid possible biases in the values which could have arisen from soil ingestion by the grazing animals or soil contamination of the consumed forage, both of which would elevate faecal ash and faecal DM output and hence estimates of feed intake.

It was concluded from the statistical analysis, that in all but one situation (OM, diet W2), no differences in variance between the regressions for the respective indoor and outdoor values could be established and consequently the indoor and outdoor results within each period (except W2) were combined and the best-fit, linear or quadratic relations were developed (see Figs. 2 and 3). For diet W2, the OM results were weighted by the reciprocal 


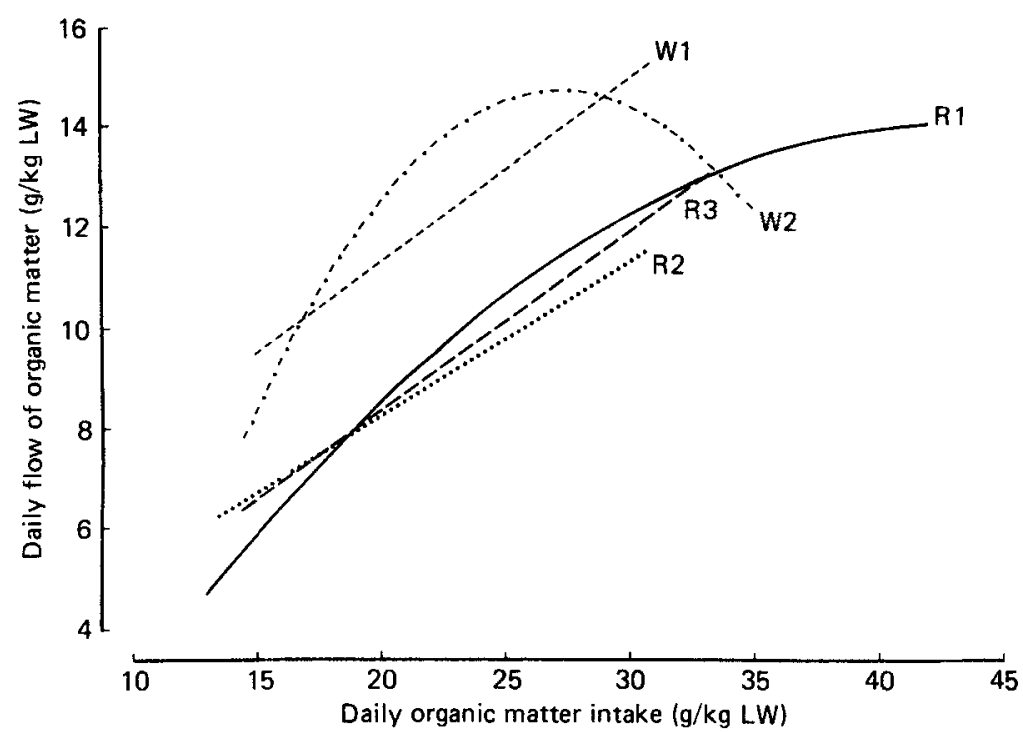

Fig. 2. The relations between organic matter flow to the small intestine ( $Y, \mathrm{~g} / \mathrm{kg}$ live weight (LW) per d) and organic matter intake ( $X, \mathrm{~g} / \mathrm{kg} \mathrm{LW}$ per d) for cattle grazing or fed on harvested perennial ryegrass (Lolium perenne cv. Melle; R1, R2 and R3) and white clover (Trifolium repens cv. Blanca; W1 and W2) forages.

$$
\begin{aligned}
\mathrm{R} 1: Y=0.865 X-0.0099 X^{2}-4.876, r^{2} 0.90, \text { residual SD (RSD) l.048; } \\
\text { R2: } Y=0.307 X+2.059, r^{2} 0.734, \text { RSD } 0.940 \\
\text { R3: } Y=0.351 X+1.304, r^{2} 0.581, \text { RSD 1.440; } \\
\text { W1 : } Y=0.359 X+4.083, r^{2} 0.560, \text { RSD 1.549; }
\end{aligned}
$$$$
\text { W2: } Y=2.277 X-0.0415 X^{2}-16.512, r^{2} 0.783 ; \text { RSD }-1.116
$$

of the variance obtained from separate regressions and, from overall regression analysis of the weighted data, a quadratic relation for the combined indoor and outdoor values was derived.

From this overall analysis of the results of the grazing experiment combined with the values obtained with cut forage, a further basis on which to examine the effect of forage species, stage of maturity of the forage and level of feeding on nutrient digestion and supply in young cattle was developed.

\section{Digestion of fresh forages}

From the combined relations presented in Fig. 2 it can be seen that on the legume diets, between 2 and $4 \mathrm{~g}$ extra $\mathrm{OM} / \mathrm{kg}$ live weight per $\mathrm{d}$ entered the small intestine compared with the grass diets; the effect being similar in magnitude to the response to forage species reported earlier by Beever et al. (1986a). In the present experiment, no attempts were made to characterize the origin of the extra OM flow, although it would appear reasonable to conclude on the basis of findings presented by Beever \& Siddons (1986) that a major part could be attributed to an increased synthesis of microbial protein within the rumen.

Despite distinct leaf: stem ratios and differing chemical compositions, the regressions for OM presented for the three ryegrasses (Fig. 2) were virtually indistinguishable, with OM flow to the small intestine averaging between 0.36 and 0.40 of $\mathrm{OMI}$ at the two extremes of OMI achieved (i.e. 15 and $32 \mathrm{~g} \mathrm{OM} / \mathrm{kg}$ live weight).

In contrast, the $\mathrm{N}$ digestion values presented in Fig. 3 indicated a broad compatability 




Fig. 3. The relations between non-ammonia-nitrogen (NAN) flow to the small intestine $(Y, \mathrm{~g} / \mathrm{kg}$ live weight ( $\mathrm{LW}$ ) per d) and $\mathrm{N}$ intake $(X, \mathrm{~g} / \mathrm{kg} \mathrm{LW}$ per d) for cattle grazing or fed on harvested perennial ryegrass (Lolium perenne cv. Melle; R1, R2 and R2) and white clover (Trifolium repens cv. Blanca: WI and W2) forages.

$$
\begin{gathered}
\mathrm{R} 1: Y=1 \cdot 746 X-0.564 X^{2}-0.423, r^{2} 0.892, \text { residual SD (RSD) } 0.085 ; \\
\text { R2: } Y=0.506 X+0.183, r^{2} 0.789, \text { RSD } 0.068 \\
\text { R3: } Y=1.348 X-0.117, r^{2} 0.656, \text { RSD } 0.090 \\
\text { W1: } Y=0.765 X-0.006, r^{2} 0.507, \text { RSD } 0.102 \\
\text { W2: } Y=2.684 X-1.024 X^{2}-0.913, r^{2} 0.712, \text { RSD } 0.083
\end{gathered}
$$

with respect to forage species and stage of growth, except for diet R3. With all other diets, NAN flow to the small intestine was less than $\mathbf{N}$ intake and the extent of this loss increased as $\mathrm{N}$ intake increased, especially on diets $\mathrm{R} 1$ and $\mathrm{W} 2$ where quadratic equations were established. This effect is in broad agreement with the values presented by Ulyatt \& Egan (1979) from a collation of values obtained on the digestion of forages by sheep. In contrast, diet R3, which was characterized by a low $\mathrm{N}$ content, gave small net gains of $\mathrm{N}$ across the rumen at all levels of intake achieved, although it can be seen from Fig. 3 that high $\mathbf{N}$ intakes corresponding to those seen on the other four diets were not achieved with this diet.

When all the indoor and outdoor results for all diets were combined and duodenal NAN flow (expressed as $\mathrm{g} / \mathrm{g} \mathrm{N}$ intake, $Y$ ) was related to $\mathrm{N}$ concentration in the forage $\mathrm{OM}(\mathrm{g} /$ $\mathrm{kg}, X$ ), the following equation was obtained:

$$
Y=1.430-0.0169 X, r-0.72 \text {, residual sv } 0 \cdot 140,
$$

indicating that when forage $\mathrm{N}$ content exceeded $25.5 \mathrm{~g} / \mathrm{kg}$, net losses of $\mathrm{N}$ between the diet and the duodenum would occur, whilst at a concentration of $40 \mathrm{~g} \mathrm{~N} / \mathrm{kg} \mathrm{OM}$ in the forage, NAN flow to the small intestine would be only 0.75 of $\mathrm{N}$ intake. Equally, at a concentration of $22.1 \mathrm{~g} \mathrm{~N} / \mathrm{kg}$ OM as found in diet R3, duodenal NAN flow would be expected to be 1.06 times $\mathrm{N}$ intake, a finding in broad agreement with the values presented in Fig. 3. Support for this overall summary of the results is provided by the earlier studies of Hogan \& Weston (1970) and more recently by Beever \& Siddons (1986). 


\section{Consequences for $N$ utilization}

The results of the present study have confirmed earlier observations by Beever et al. (1985, $1986 a, b)$ and others that in animals given high-quality forages, a significant proportion of the ingested $\mathrm{N}$ may fail to reach the small intestine as NAN and is probably absorbed from the rumen as ammonia. This effect appears to be due to imbalance in the rumen between degraded $\mathrm{N}$ and degraded energy supply (Beever $e t$ al. 1986a). It has been demonstrated (Black et al. 1979; Barry et al. 1982; Thomson et al. 1984) that animals consuming fresh forages, particularly grass, will respond, in terms of increased animal performance, to protein supplements but it may ultimately be possible to achieve similar effects by manipulation of forage composition through the introduction of plant tannins (Thomson et al. 1971; Barry \& Manley, 1984) or the use of protein protection agents (Beever et al. 1987) or energy-rich supplements.

\section{Conclusions}

It is evident from the present study that the infusion and sampling apparatus described by Evans et al. $(1981 a, b)$ provided realistic estimates of nutrient flow to the small intestine of grazing ruminants. It is also evident that current knowledge on the nutritive value of fresh forages is limited. Whilst the findings obtained in the present study are useful, further research to investigate the effect of factors such as forage species, variety, sward management and animal-plant interactions on the nutritive value of fresh forage is urgently required. What currently remains uncertain is whether fresh forages can be evaluated by cutting and feeding to housed animals and the results applied with confidence to animals grazing pasture. Given the findings of the present study, it is reasonable to conclude at this stage that both options may be of value in evaluating grazed forage, and to disregard the usefulness of direct measurements of nutrient supply in grazing animals would be premature.

One of us (M.J.U.) received financial support from the AFRC Underwood Fund. Further financial assistance was received from Sinclair McGill, Finney Lock, Miln Masters and Nickerson. All sources are gratefully acknowledged. The authors wish to thank Professor A. Lazenby and Professor D. F. Osbourn for support and advice, and Messrs A. R. Austin, S. B. Cammell, K. V. Skelton, N. Grover, D. L. Gale, M. C. Spooner and R. J. Barnes, the staff of the Analytical Chemistry Laboratory, and M. S. Dhanoa for the technical assistance given to the experiment. The Animal and Grassland Research Institute is financed through the Agricultural and Food Research Council and part of this work was commissioned by the Ministry of Agriculture, Fisheries and Food.

\section{REFERENCES}

Agricultural Research Council (1980). The Nutrient Requirements of Ruminant Livestock Farnham Royal: Commonwealth Agricultural Bureaux.

Baker, R. D. (1978). Proceedings of the British Grassland Society 119-126.

Baker, R. D., Alvarez, F. \& Ledu, Y. L. P. (1981). Grass and Forage Science 36, 189-199.

Barry, T. N. \& Manley, T. W. (1984). British Journal of Nutrition 51, 493-504.

Barry, N. N., Manley, S. R., Davis, S. R. \& Redekopp, C. (1982). In Forage Protein in Ruminant Animal Production, Occasional Publication of the British Society of Animal Production no. 6, pp. 146-148 [D. J. Thomson, D. E. Beever and R. G. Gunn, editors]. Thames Ditton: British Society of Animal Production.

Bartlett, M. S. (1937). Proceedings of the Royal Society 160, 262-282.

Beever, D. E., Cammell, S. B. \& Wallace, A. S. (1974). Proceedings of The Nutrition Society 33, 73A.

Beever, D. E., Dhanoa, M. S., Losada, H. R., Evans, R. T., Cammell, S. B. \& France, J. (1986a). British Journal of Nutrition \$6, 439 454.

Beever, D. E., Losada, H. R., Cammell, S. B., Evans, R. T. \& Haines, M J. (1986 b). British Journal of Nutrition 56, 209-225. 
Beever, D. E., Losada, H. R., Gale, D. L., Spooner, M. C. \& Dhanoa, M. S. (1987). British Journal of Nutrition 57, 57-67.

Beever, D. E. \& Siddons, R. C. (1986). In Control of Digestion and Metabolism in Ruminants. Proceedings of VIth International Symposium on Ruminant Physiology, pp. 479-497 [L. P. Milligan, W. L. Grovum and A. Dobson, editors]. Englewood Cliffs, New Jersey: Prentice Hall.

Beever, D. E., Terry, R. A., Cammell, S. B. \& Wallace, A. S. (1978). Journal of Agricultural Science, Cambridge 90, 463-470.

Beever, D. E., Thomson, D. J. \& Cammell, S. B. (1976). Journal of Agricultural Science, Cambridge 86, $443-452$.

Beever, D. E., Thomson, D. J., Ulyatt, M. J., Cammell, S. B. \& Spooner, M. C. (1985). British Journal of Nutrition 54, 763-775.

Black, J. L., Dawes, S. T., Colebrook, W. F. \& James, K. J. (1979). Proceedings of the Nutrition Society, Australia 4, 126.

Corbett, J. L., Furnival, E. P., Inskip, M. W., Perez, C. J. \& Pickering, F. S. (1976). Proceedings of the Australian Society of Animal Production 11, 329-332.

Cruikshank, G. J., Poppi, D. P. \& Sykes, A. R. (1985). Proceedings of the New Zealand Society of Animal Production 45, 113-116.

Evans, C. C., MacRae, J. C. \& Wilson, S. (1977). Journal of Agricultural Science, Cambridge 89, 17-22.

Evans, R. T., Hayes, D. G. \& Beever, D. E. (1981 a). Laboratory Practice 30, 591-593.

Evans, R. T., Skelton, K. V. \& Beever, D. E. (1981 b). Laboratory Practice 30, 997-1000.

Faichney, G. J. (1975). In Digestion and Metabolism in the Ruminant, pp. 277-291. [I. W. McDonald and A. C. I. Warner, editors]. Armidale, Australia: University of New England Publishing Unit.

Hogan, J. P. \& Weston, R. H. (1970). In Physiology of Digestion and Metabolism in the Ruminant, pp. $474-485$ [A. T. Phillipson, editor]. Newcastle upon Tyne: Oriel Press.

Kotb, A. R. \& Luckey, T. D. (1972). Nutrition Abstracts and Reviews 42, 813-845.

Langlands, J. P. (1975). In Digestion and Metabolism in the Ruminant, pp. 320-332. [I. W. McDonald and A. C. I. Warner, editors]. Armidale, Australia: University of New England Publishing Unit.

MacRae, J. C. \& Ulyatt, M. J. (1974). Journal of Agricultural Science, Cambridge 82, 309-319.

Thomson, D. J., Beever, D. E., Haines, M. J., Cammell, S. B., Evans, R. T., Dhanoa, M. S. \& Austin, A. R. (1984). Journal of Dairy Research 52, 17-31.

Thomson, D. J., Beever, D. E., Harrison, D. G., Hill, I. W. \& Osbourn, D. F. (1971). Proceedings of the Nutrition Society 30, 14A.

Ulyatt, M. J. \& Egan, A. R. (1979). Journal of Agricultural Science, Cambridge 92, 605-616.

Ulyatt, M. J. \& MacRae, J. C. (1974). Journal of Agricultural Science, Cambridge 82, 295-307.

Verite, R., Remond, B. \& Journet, M. (1984). Canadian Journal of Animal Science 64, Suppl., 328-329. 